\title{
On the Influence of Freudian Psychoanalysis on Aesthetics
}

\author{
Yue Jiang \\ Sichuan University of Arts and Science, Dazhou, China \\ Email:47872614@qq.com
}

How to cite this paper: Jiang, Y. (2019) On the Influence of Freudian Psychoanalysis on Aesthetics. Open Access Library Journal, 6: e5993.

https://doi.org/10.4236/oalib.1105993

Received: December 11, 2019

Accepted: December 24, 2019

Published: December 27, 2019

Copyright $\odot 2019$ by author(s) and Open Access Library Inc.

This work is licensed under the Creative Commons Attribution International License (CC BY 4.0).

http://creativecommons.org/licenses/by/4.0/

\begin{abstract}
The psychoanalytic theory of Sigmund Freud, the founder of psychoanalytic school, especially his "unconsciousness" theory and "libido" theory has a profound positive or negative influence on aesthetic theory, especially the theory of aesthetic creation and criticism. This paper attempts to tease out some of its effects and make some analysis and evaluation.
\end{abstract}

\section{Subject Areas}

Literature, Psychology

\section{Keywords}

Sigmund Freud, Unconsciousness, Libido, Aesthetics, Influence

\section{An Introduction to Freud and His Works}

As an Austrian psychiatrist, a psychiatrist, a psychologist, the founder of psychoanalysis Sigmund Freud (1856-1939) is a very important modern scholar in humanity and social science field. He successively published The Interpretation of Dreams (1900), Three Essays on the Theory of Sexuality (1905), Totem and Taboo (1913), The Ego and the Id (1923), Civilization and Its Defects (1929), and other works since 1900, creating the psychoanalytic school which has made a far-reaching influence in the twentieth century. The Interpretation of Dreams offers three perspectives. First, dreams are a spiritual activity arising out of desires, and their contents are "the fulfillment of wishes"; Second, the dream is the subconscious self-expression: do everything possible to break through the pre-conscious field to emerge; Third, dreams are similar to psychosis in that both conform to the activity of the unconscious mind. Through the techniques of psychoanalysis, the book Three Essays on the Theory of Sexuality makes a 
systematic analysis and research on the problem of sex by using the actual data of treating patients. As an anthropological and psychoanalytic work, Totem and Taboo focuses on incest's fear, taboo and ambivalence, Sprite theory, the omnipotence of witchcraft and thought, and totem worship's reappearance in childhood. The Ego and The Id is an important treatise on the revision, supplement and development of psychoanalysis by Freud in his later period; this book deeply expounds human instinct, group psychology, id, ego, superego and other concepts and their mutual relations. Civilization and Its Defects offers a rational analysis based on psychoanalytic perspective on the development of western society, culture and civilization, religion and other issues. Although his students and successors Jung, Adler, Lacan and other scholars constantly revised and even overturned his theory, Freud, as the originator of classical psychoanalysis, had a great influence on psychology, philosophy, art and many other fields. For example, Freudian psychoanalysis created many new academic fields such as personality psychology, dynamic psychology and abnormal psychology etc., and promoted the development of self-psychology. Freud's theory of the unconscious plays a very important role in the whole modern western philosophy, based on the unconscious theory, he established an unprecedented system of psychological philosophy, a psychoanalytic theory about unconscious activities, and he himself is called the father of the unconscious. Because of his great contribution to academic thought, he became one of the three great thinkers in the modern world, together with Marx and Nietzsche. In view of the limitation of education, this paper does not intend to systematically discuss the whole psychoanalytic theory, but only intends to make a rough analysis of the influence of Freudian psychoanalytic theory on aesthetics.

\section{A General Introduction to Freud's Theory}

Before we begin, I think we need to give a general introduction to Freud's theory. The most prominent feature of Freudian psychoanalysis is the discovery of the unconscious. When he studied the human psychological structure, he found that the human psychological structure can be divided into three layers, namely the unconscious, the preconscious and the conscious. To illustrate their effects, he likens the human brain to an iceberg in the sea, noting that "the conscious part is like the little part above the surface of the sea; The part of preconsciousness that is at sea level, rising and falling with the waves of the water; The unconscious is the vast majority of the body submerged in the sea." [1] Through this example, he vividly illustrates the dominance of the unconscious in human consciousness. In response, he proposed the famous structure theory of the triple personality (eide, ego, superego), indicating that everyone has such a triple personality, and cited a large number of literary characters to prove that human behavior in most cases is controlled by eide (id). Another important theory of Freud was his libido theory. Libido refers to the latent energy associated with the sexual instinct, which was later expanded to an instinctive desire to live, to seek 
pleasure and to escape pain, and to the motivational force of the living instinct as opposed to the death instinct. Libido theory is actually based on the theory of the unconscious. He points out that human motivation and desire, especially sexual desire (libido), mostly exist in the unconscious. Through deeper research, he further points out that everyone, even including infants, have sexual impulse, a special performance on attachment to parents, which he called "Oedipus complex". However, bound by the superego, the vast majority of people will choose other ways to vent this lust, such as, they will choose writing creation of art and literature. Moreover, in The Interpretation of Dreams, he has brilliantly analyzed the mechanics of dreams: in dreams, one thing is condensed into something else, one person is replaced by another, and the dreamer's wishes are often fulfilled in disguise [2]. In this way, Freud established his own huge system centering on the theory of the unconscious, and opened up a wide field of vision for the study of other disciplines. However, Freud's unconscious theory emphasizes too much on human biology and human instinct, ignoring human sociality and the decisive influence of social and cultural environment on human behavior, which has certain limitations.

Though Freud's theory was later constantly revised by many scholars, including his students, but its influence is also almost ranging throughout the twentieth century worldwide. As American psychologist Erich Fromm said: "Indeed, not Freud first discovered the phenomenon of the subconscious, but Freud was first discovered in this phenomenon as the center has established the system of psychology. He studied deeply and in detail the subconscious phenomenon, made amazing achievements." [3] There is no doubt that Freudian psychoanalysis is worthy of serious studied, whether in psychology, art or otherwise. Below, we should discuss its influence for aesthetic theory, especially about the aesthetic art branch.

\section{The Influence of Freudian Psychoanalysis on Aesthetics}

Freudian psychoanalysis has a profound influence on aesthetics. He put forward some enlightening views on aesthetic art such as literary creation and literary criticism, etc. For example, Freud believed that libido is the motive force of aesthetic creation, and the essence of art lies in the "sublimation" of artists' repressed sexual instinct. Artists, whose instinct has been suppressed by consciousness for a long time and cannot be satisfied, try to express it in the form of literary creation and finally obtain a satisfying happiness. Therefore, their creation motivation is "sexual impulse". Through sublimation, the repressed libido gets the release way and form permitted by social morality. Thus the function of literature and art was interpreted by him as a compensatory function. At the same time, he based on a famous ancient Greek tragedy The King Oedipus to create the important concept of the so-called "Oedipus complex" which is a common feeling in the human unconsciousness and an important root of the artists creative impulses. Hence, mother (father) complex is the eternal subject of 
aesthetic expression. He also equates writers with dreamers, holding that daydreaming is the activity mode of artists' aesthetic creation, and that literature and art are similar to dreams, and that literature and art are nothing but unconscious desires or a symbol of sex, which are writers' daydreams. The vast majority of dreams are after the modification and transformation, and modification and transformation is the basic method of artistic creation. These views and revisions of them by later generations led directly to the emergence of a new aesthetic school, psychoanalytic aesthetics.

Now let's look at Freud's contribution to aesthetics from the following aspects:

According to Freud's theory of the unconscious, consciousness and the unconscious are opposites. Consciousness suppresses the unconscious instinct impulse, so that it can only get the disguised and symbolic satisfaction; unconsciousness is the basic motive force of psychological activities, which secretly dominates consciousness. The theory of unconsciousness reveals the complexity and hierarchy of human psychology, guides people to pay attention to the motive behind consciousness, and probes into the influence of unconscious psychology on human behavior, which has played a great role in enlightening writers and critics in the $20^{\text {th }}$ century. Literary artists no longer stay in the expression of human consciousness, but go deep into the unfathomable unconscious field to explore the mysteries of the mind and reveal the rich inner world of human being. It can be said that the theory of the unconscious opens up a broader field of expression for the creative theory of art (especially literature), expands the space of the inner world of the characters, and raises the psychoanalytic technique in literary works to a new level. As to the performance in the field of western literary creation, even many Chinese literatures in the 1920-30s and 1980s, a lot of unconscious activities have expressed as the main focus in many great works like Joyce's Finnegans Wake. Of course, the theory of the unconscious brings not only positive things to the aesthetic field, but also many negative effects such as belittling the role of consciousness and rationality

According to his theory of triple personality structure and "libido," Freud held a pansexual view in literary creation and criticism, that is, he regarded sexual desire as the motivation of literary creation. Writers and artists are driven by their "instinctive desires"-their "sexual urges". He went on to argue that literature and art were essentially a "sublimation" of repressed sexual impulses. Through sublimation, the repressed libido can be satisfied by means or forms permitted by social morality. According to this "sublimation theory," the function of literature and art is interpreted as a compensation function. Writers and readers' unfulfilled desires in real life can be satisfied through creation or appreciation of literary and artistic works. At the same time, the concept of the Oedipus complex, which he derived from the libido theory and the theory of personality, was also regarded by him as a universal truth. Taking Sophocles' The King Oedipus, Shakespeare's Hamlet and Dostoevsky's Karamazov Brothers as examples, he applied this theory to the field of literary research, which had a great influence 
on western literary creation and criticism. The literature and art creation domain describes this kind of abnormal emotion and the work also arises at this historic moment. It should be noted that "Oedipus complex" cannot be used to explain all phenomena of aesthetic creation, even if it can become a motif of literary creation. If we take it as an irrefutable truth and ignore the decisive role of social life in aesthetic creation, we will fall into a ridiculous and pathetic situation.

In addition, according to his dream interpretation theory, Freud believed that literature, art and dreams had many common characteristics. Secondly, the relationship between the content of the dream and the subconsciousness is just like the relationship between the form and the meaning of literary works. Literature and dream are in fact a substitute, a spiritual phenomenon with full value. Thirdly, the method of dream interpretation is similar to that of literary criticism, which is to discover and reveal the "potential" meaning. Based on this, he divided artists into two categories: those who, like the ancient writers of heroic epics, accepted ready-made material. The other is creative writers, who create their own material. He thought that the latter kind of imaginative and creative artists were similar to dreamers under the "broad daylight," and further pointed out that literary creation was just a daydream of artists. His views have certain positive significance for aesthetic creation: they inspire artists to break through the boundaries of real life, give full play to their creativity and subjectivity, and create imaginative works of art. But we should also know that his theory of dream interpretation is incomplete in itself, and cannot fully explain the cause of dreams.

At the same time, the influence of Freudian psychoanalysis on aesthetics is not only shown in the above positive aspects, but also has some negative effects. On the one hand, due to the excessive worship of the Oedipus complex, some scholars blindly interpret literary and artistic works with far-fetched interpretation, thus mistakenly interpreting some works with strong social characteristics from the perspective of physiological instinct. On the other hand, by mechanically attributing all artistic creation to sexual instinct, some people "exaggerating a correct theory to the point of absolute eroticism," and denying the materialistic fact that artistic creation is a "reflection of the phenomenon of human social life," they fall into an idealist trap of artistic creation. Therefore, while fully affirming the academic contribution of Freudian psychoanalysis, we should be soberly aware that we cannot completely rely on it to guide our creation and theoretical research.

\section{Conclusion}

In short, Freud became the originator and master of psychoanalysis for his pioneering work, and had a great influence on the theoretical field in the $20^{\text {th }}$ century. In the field of aesthetic art, especially literary creation and interpretation, although his theory still has its own inevitable defects, it greatly broadens 
people's vision and expands the field of aesthetic research. This paper summarizes, analyzes and makes some comments on the main viewpoints of Freudian psychoanalysis, and points out the contribution and negative influence of this theory to the theory of aesthetic creation. Since the thinking of this paper is limited to the theory of aesthetic creation, and the profound influence of Freudian psychoanalysis on the whole modern aesthetic theory is still little explored, it should be said that the discussion is not in-depth enough. This is one of the questions that we need to explore further.

\section{Conflicts of Interest}

The author declares no conflicts of interest regarding the publication of this paper.

\section{References}

[1] 朱立元 (1997) 当代西方文艺理论. 上海: 华东师范大学出版社.

[2] Freud, S. (1900) The Interpretation of Dreams. 朱更生, 译. 杭州: 浙江工商大学 出版社.

[3] Fromm, E. (1979) Greatness and Limitation of Freud's Thought. 申荷永, 译. 长 沙: 湖南人民出版社. 